\title{
Terrane de Ana Lira | Trauma de Ivan Padovani: o discurso do artista, o discurso da obra
}

\author{
Mariano Klautau Filho ${ }^{1}$ e Jorge Leal Eiró da Silva ${ }^{2}$
}

Resumo: Análise de aspectos das obras Terrane de Ana Lira ${ }^{3}$ e Trauma de Ivan Padovani ${ }^{4}$, considerando suas montagens na mostra Realidades da Imagem, Histórias da Representação, no Museu do Estado do Pará, Belém, em 2018. Adota-se como base teórica as discussões sobre autonomia da obra e suas relações sociais, incluindo, nesse percurso, o discurso do artista e seu lugar como ator político e, ainda especialmente, o discurso que emerge do trabalho, de sua feição formal e material no espaço expositivo.

Palavras-chave: Ana Lira, Ivan Padovani, Poética-política, Forma-discurso

\section{Terrane by Ana Lira | Trauma by Ivan Padovani: the artist's speech, the speech of the artwork}

Abstract: Analysis on aspects of the works Terrane by Ana Lira, and Trauma by Ivan Padovani, considering their exhibitions in the show Realidades da Imagem, Histórias da Representação, at Museu do Estado do Pará, Belém, in 2018. As a theoretical basis, we propose discussions on the autonomy of artwork and its social relations, including, during this course, the speech of the artist and his role as a political actor and, specially, the discourse that emerges from the artwork, from its formal and material appearance in the exhibition space.

Keywords: Ana Lira, Ivan Padovani, Poetics-politics, Form-discourse

1 Artista, pesquisador e curador. Doutor em Artes Visuais - ECA/USP e mestre em Comunicação e Semiótica PUC/SP. Professor da Universidade da Amazônia. Curador do Diário Contemporâneo de Fotografia, em Belém e Antilogias: o fotográfico na Pinacoteca, em São Paulo (2017). Como artista participou das mostras Triangular: arte deste século - Casa Niemeyer - Brasília (2019/2020), Feito poeira ao vento - Fotografia na Coleção MAR - RJ (2017/2018) entre outras. Obras em acervos: MAM-SP, Coleção Joaquim Paiva - RJ, Coleção Pirelli/MASP - SP, MAR - RJ, entre outros. Universidade da Amazônia (PPGCLC/UNAMA).E-mail: marianokf@uol.com.br. ORCID: https://orcid.org/0000-0002-0061-135X. Lattes iD: http://lattes.cnpq.br/8786771910755876. Belém, Brasil.

2 Arquiteto, artista plástico e curador independente. Mestre e doutor em Educação pela UFPA. Professor do PPGCLC/ UNAMA-PA, no qual integra o Projeto de Pesquisa "Arte Contemporânea nos Acervos de Museus Paraenses: 19802016". Professor Adjunto da FAU/UFPA. Realizou diversas exposições individuais e coletivas no Brasil e no exterior. Membro do conselho curador do Museu de Arte do CCBEU-PA. Universidade da Amazônia (PPGCLC/UNAMA). E-mail: eirojorge@gmail.com. ORCID: https://orcid.org/0000-0002-2293-3958. Latte iDs: http://lattes.cnpq. br/8764074383420233. Belém, Brasil.

3 Ana Lira (Caruaru, PE, 1977) É especialista em Teoria e Crítica de Cultura. Vive em Recife e desenvolve trabalhos de pesquisa independente, curadoria e projetos educacionais articulados com projetos visuais. Participou de diversas exposições como Não-Dito (CAL, Brasília, 2019; CCBEU, Prêmio Funarte de Arte Contemporânea, Belém, 2017; CCI, Recife, 2015); Arte Democracia Utopia (MAR, Rio de Janeiro, 2018-2019) com o coletivo Amò; Agora Somos Todxs Negrxs (VideoBrasil, São Paulo, 2017), Antilogias: o fotográfico na Pinacoteca (Pinacoteca de São Paulo, 2017); Fotos Contam Fatos (Galeria Vermelho, São Paulo - 2015/2016); 31a Bienal Internacional de Arte de São Paulo (São Paulo, 2014) entre outras. É autora do livro Voto, publicado pela editora independente Pingado Prés. Em 2019, foi artista residente no Delfina Foundation em Londres.

4 Ivan Padovani (São Paulo, SP, 1978) Artista, Pós Graduado em Fotografia pela FAAP-SP. Professor na Escola Panamericana de Arte. Desde 2016 integra o Vão, espaço independente voltado para pesquisa, produção e exposições de arte contemporânea. Seu projeto Campo Cego foi apresentado na exposição Time - Space - Existence que fez parte da $15^{2}$ Bienal Internacional de Arquitetura de Veneza, da mostra Antilogias: o fotográfico na Pinacoteca de São Paulo e da Bienal de Arquitetura de São Paulo 2017. Bolsista do Programa Descubrimientos no Festival PhotoEspaña do mesmo ano e finalista do Concurso Conrado Wessel de Fotografia com o projeto Superfície. 


\section{Introdução}

A mostra Realidades da Imagem, Histórias da Representação reuniu em todas as salas expositivas do espaço térreo do Museu do Estado do Pará - MEP, incluindo pátios internos e fachada lateral, a produção recente de 30 artistas de diversas regiões do país. A mostra, resultante da nona edição do Prêmio Diário Contemporâneo de Fotografia, representou parte de um conjunto de exposições, atividades e encontros em torno da arte contemporânea tendo como eixo a imagem fotográfica e suas relações com variados dispositivos da linguagem artística. ${ }^{1}$ Partimos da pergunta sobre o lugar da arte e o lugar do artista nas tensões entre poética e política sugerida no mote temático da edição de 2018, por, pelo menos, duas razões: inicialmente por se tratar de uma pauta fundamental da cena contemporânea que é a emergência das discussões políticas no mundo e no Brasil. Somado a isso, ou melhor, tomando as contingências como arranque, convocar a necessidade sempre renovada de pôr em pauta uma discussão que é da arte, especialmente. Em perspectiva histórica e crítica, pensarmos as rupturas acontecidas mais verticalmente a partir dos anos 1960 e 70, momento em que as experiências conceituais trouxeram para dentro do campo artístico uma inflexão filosófica cuja contundência provocou um processo de questionamento dos limites, da função, da materialidade e, especialmente nesse caso, da própria condição política da arte.

Com a proposição Realidades da Imagem, Histórias da Representação pretendíamos provocar um tensionamento no artista quando este pensasse seu projeto poético como atitude política. Entretanto, por estratégia, não utilizamos a palavra política no texto da convocação. O artista e teórico norte-americano Allan Sekula, em abordagem documental da fotografia e suas relações com a história da arte, trata das instâncias entre as políticas de representação e as representações políticas. ${ }^{2}$ Esse pensamento esteve

1 O Diário Contemporâneo de Fotografia é um projeto de arte realizado em Belém desde 2010 por uma empresa de comunicação, Jornal Diário do Pará, em parceria com duas instituições públicas: Sistema Integrado de Museus - Secult Pará e Museu de Arte da Universidade Federal do Pará. O projeto envolve exposições, encontros com artistas, palestras, conferências, cursos e oficinas com curadoria geral de Mariano Klautau Filho. A proposição temática para a edição de 2018, Realidades da Imagem, Histórias da Representação, norteou o trabalho da comissão formada por Walda Marques, Flavya Mutran e Rosely Nakagawa.

2 SEKULA, Allan. Desmantelar la modernidad, reiventar el documental: notas sobre la política de la representación. In: RIBALTA, Jorge. Efecto real: debates posmodernos sobre 
no fundo das questões propositivas para a edição de 2018 quando resolvemos nomeá-la Realidades da Imagem, Histórias da Representação, e nos equipou conceitualmente para a provocação sobre as inconstâncias entre fotografia e realidade e entre arte e história social.

A fotografia tem reivindicado (e conquistado) o direito à ficção e a recusa à realidade, mas é inegável reconhecer que a sua relação de ambiguidade, manifesta nos processos de representação do mundo real, não seja sua mola propulsora, considerando a realidade um elemento determinante no trabalho fotográfico. De modo mais amplo, a arte permanece reivindicando seu direito a uma autonomia plena, absoluta, em suas questões materiais, técnicas e conceituais. No entanto, é importante reconhecer que sua dinâmica, manifesta em seus processos de representação, não esteja em constante instabilidade por seu vínculo com a realidade e sua história social.

Nos capítulos iniciais de seu livro $O$ que resta: arte e crítica de arte $^{3}$, Lorenzo Mammi retoma a ideia da morte da arte, assinalando que o tema existe desde Hegel, como um dos pontos centrais das discussões entre historiadores e filósofos nos últimos trinta anos. A ideia central reside no fato em que as mudanças operadas na arte nas últimas décadas foram tão radicais e profundas que provocaram uma "fratura irrecurável" tanto na arte moderna quanto na história da arte como um todo. Para Mammi, não há mais como recuperar a arte tal como esta costumava ser compreendida em seus antigos pressupostos: seja em seus modos de produção, apreensão, inserção na sociedade, representação da realidade, enfim, seu modo político de ser. Entre os teóricos (da morte da arte) que Mammi destaca estão Giulio Carlo Argan e Arthur Danto ${ }^{4}$, que, em sua opinião, ocupam polos extremos de análise. Seguindo Argan, Lorenzo Mammi menciona a dificuldade de se fazer crítica, de exercer o ofício da crítica tendo como referência a arte produzida nos anos 1960 e 70, exatamente no contexto

fotografía. Barcelona: Editorial Gustavo Gigli, SA, 2004

3 MAMMI, Lorenzo. O que resta : arte e crítica de arte / Lorenzo Mammì. - $1^{a}$ ed. - São Paulo : Companhia das Letras, 2012.

4 O autor cita ARGAN, especialmente no capítulo A crise da crítica e a crise da arte, em Arte e Crítica de Arte, 1984; DANTO em Após o fim da arte, 1997. Mammi também menciona o ensaio de Hans Belting, O fim da história da arte, $(1983,1987,2006)$ que considera um pouco diferente na abordagem, embora com elementos importantes para a discussão que propõe. 
da ruptura conceitual dos processos artísticos, em seus aspectos materiais, experimentais e filosóficos. Sob essa chave, a arte, naquele momento, recusaria a crítica estabelecida de duas formas. Uma delas seria a partir da ideia de uma arte misturada à vida, que só possuiria valor se calcada na experiência social, medida não por um julgamento que estivesse fora dela, distante e formal, e sim porque estaria criticamente atrelada à experiência do mundo, uma experiência, sobretudo, ética e política. A outra via trata da concepção de arte que defendia autonomia plena e absoluta. Ou seja, a arte sendo ela mesma um modo crítico, uma filosofia:

Essa arte se punha como uma estrutura de signos que teria seu valor em si, independentemente de qualquer contexto histórico ou biográfico. Era uma arte que se pretendia totalmente objetiva, no sentido de que o mundo não interferiria nela. (...) Portanto não haveria diferença entre a atividade do artista e a atividade do crítico. ${ }^{5}$

Nesse sentido, o impasse aqui constatado entre autonomia ou dependência revelaria a crise da crítica, a crise da arte ou, ainda, a crise da arte em sua relação com o mundo? Esta tensão importante, indicada nas rupturas das experiências conceituais, abriu campos de discussão não só no sentido de uma revisão do projeto moderno, construído em torno da autonomia da arte, mas também em razão de uma nova posição em que a autonomia apoiou-se no papel filosófico da arte. Naquele momento, a desmaterializacão do objeto artístico, a arte como pensamento puro e as suas reconexões com a sociedade atuaram de forma decisiva na expansão inexorável dos limites da arte.

$\mathrm{O}$ ataque à Estética efetuado pela Arte Conceitual se deu no sentido, dentre outros, de restituir ou, simplesmente, convocar definitivamente a filosofia como um elemento da arte. Não apenas como uma filosofia da arte. Não somente como uma filosofia específica, particular de alguma área. Mas, de modo enfático, como Peter Osborne resume: "da filosofia mesma, da filosofía como tal"6. Para Osborne, a arte conceitual não é somente um tipo particular de arte, como se possuísse um gene a mais, ou um manifesto exclusivo de um movimento. De forma mais ampla, não

\footnotetext{
5 Mammi, 2012, p.18.

6 Tradução nossa: "de la filosofía misma, de la filosofía como tal”. OSBORNE, Peter. "Arte conceptual y/como filosofía in El arte más allá de la estética. Ensayos filosóficos sobre arte contemporáneo". CENDEAC, 2010, p. 80.
} 
restrita a uma vertente, propõe-se como uma arte que quer redefinir a própria ideia de arte. Ou melhor: reconfigurar seu gene para que a arte opere como modo filosófico.

Esta mudança de chave, possível de ser compreendida na síntese de Osborne, nos forneceu um legado cujo impacto vivenciamos na arte produzida hoje. No entanto, e ao mesmo tempo hoje, vivenciamos uma recuperação ainda mais libertadora da arte, não só como pensamento autônomo, mas também como ação direta na vida, percebida por sua consequente expansão no uso dos materiais sensíveis, no embate com a beleza plástica e com as diversas nuances da labuta formal. Nesse sentido, a tensão entre o formalismo e o conceito se vê continuamente atravessada pela experiência e, nesse contexto, algumas perguntas ressurgem: de que modo os trabalhos contemporâneos abraçam e refletem tais políticas?

Sob essas questões, a provocação do tema lançado na mostra aproximouse de uma reflexão sobre crítica e história, mas que procurou, também, aproximar-se efetivamente dos mais variados procedimentos com os quais o artista contemporâneo lança mão com muito mais liberdade nesta nossa fase denominada pós-histórica. Algumas perguntas têm como pano de fundo as reflexões sobre o papel político da arte ou, ainda, sua função poética como medida política. Tais como: quais mecanismos de ação a arte pode empregar frente ao contexto social e que possíveis papéis as imagens fotográficas na arte desempenham face às realidades concretas? Quais reflexões podemos elaborar sobre a prática social por meio da arte? O que o fazer artístico pode promover como expressão social e qual o papel que o artista desempenha nas representações históricas e nas histórias da representação?

Concentrados em suas próprias expressões, mas atentos às questões humanas, os artistas participantes da mostra tensionaram suas poéticas com vistas a uma ampliação crítica do lugar da arte no mundo social. Consequente a essa proposta, a mostra reuniu trabalhos cuja força política se apoiava tanto na dimensão plástica quanto na sua relação de forças com a vida social de onde o trabalho era origem e processo. Nesse sentido, para fomentar as discussões aqui em pauta, destacaremos dois trabalhos que refletem de modo particularmente tensivo aspectos indicados na proposição da mostra Realidades da imagem, Histórias da Representação: Terrane, de Ana Lira, e Trauma, de Ivan Padovani. Trata-se, aparentemente, de trabalhos completamente distintos, mas cuja potência nos permite pensar efetivamente a dimensão poética e política que cada um deles contém e de que forma as duas propostas se articulam numa instigante tensão dialética de semelhança e diferença. 

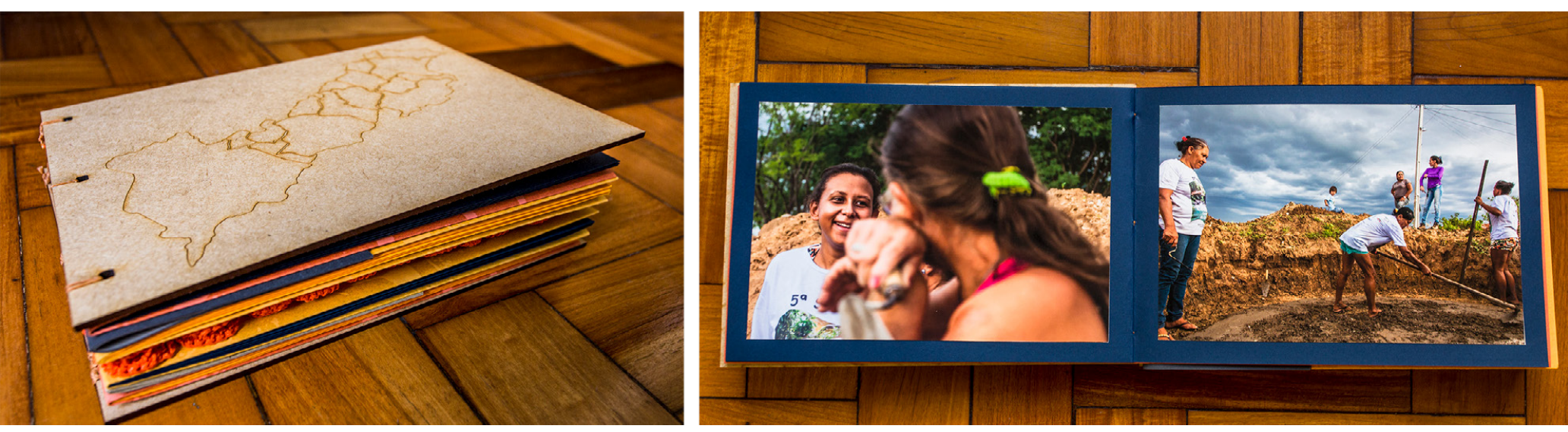

Figura 1

Ana Lira,

Terrane, 2018,

livro de artista,

$16 \times 5 \mathrm{~cm} \times 24 \mathrm{~cm}$,

Coleção da

Artista. Foto: Ana

Lira.

\section{Terrane de Ana Lira}

Terrane é em sua configuração física e visível um delicado livro de artista, de feitura artesanal, elaborado com imagens fotográficas, cartas, bordados, fotos de família, documentos, que retraçam um percurso da artista em sua vivência com comunidades das mulheres pedreiras do semiárido brasileiro. Ana Lira teve conhecimento dos primeiros indícios sobre tais comunidades a partir de relatos entre 2012 e 2013, quando acompanhava as atividades do Programa 1 Milhão de Cisternas ${ }^{7}$, no Sertão do Pajeú (PE). A partir daí pesquisou um acervo de 100 mil imagens pertencente à Articulação do Semiárido Brasileiro, até 2015. Em dois registros menores formados por cerca de 30 imagens, encontrou informações sobre experiências comunitárias desenvolvidas pela Casa da Mulher do Nordeste (CMN), desde a década de 1980. Nessas investigações, Ana percebeu o impacto da imagem criada pela indústria da seca, mas ao mesmo tempo encontrou diversas comunidades de mulheres que viviam, trabalhavam e construíam uma vida por meio de práticas distintas do sentido costumeiro de impossibilidades como é concebido a vida no semiárido nordestino. Por intermédio do contato com a CMN, tomou conhecimento dos cursos de formação para cisterneiras, quando percebeu na ação prática e na experiência de convivência com elas que a capacitação e a aptidão técnica na construção de cisternas convertia-se no fortalecimento da

7 O Programa Nacional de Apoio à Captação de Água de Chuva e outras Tecnologias Sociais ("Programa Cisternas") do Governo Federal, financiado pelo MDS desde 2003, tem como objetivo a promoção do acesso à água para o consumo humano e para a produção de alimentos por meio da implementação de tecnologias sociais simples e de baixo custo. (http://mds.gov.br/assuntos/seguranca-alimentar/acesso-a-agua-1/ programa-cisternas - acesso em 19/03/2020). 
independência econômica e social dessas comunidades. A partir de então, Ana Lira, convivendo com os trabalhos e a vida dessas mulheres, constatou:

\begin{abstract}
A escassez de documentações fotográficas sobre elas é a ponta do iceberg dos preconceitos vigentes, reforçados pelo imaginário perverso criado pela indústria da seca. Uma imagem que alimentou relatos de dor e violência, sem oferecer outras perspectivas. $^{8}$
\end{abstract}

Fruto dessa convivência e percepção, o livro surgiu como um meio em contínuo processo - de relação da artista com a comunidade das cisterneiras. O livro torna-se um canal por meio do qual a artista emerge como documentarista, como amiga, como participante dos encontros e, também, como aprendiz dos processos de construção das cisternas. A imagem apresentada a seguir é mediadora não só em seu aspecto político de documentação, mas também como um exercício poético que reage a um tipo de poder.
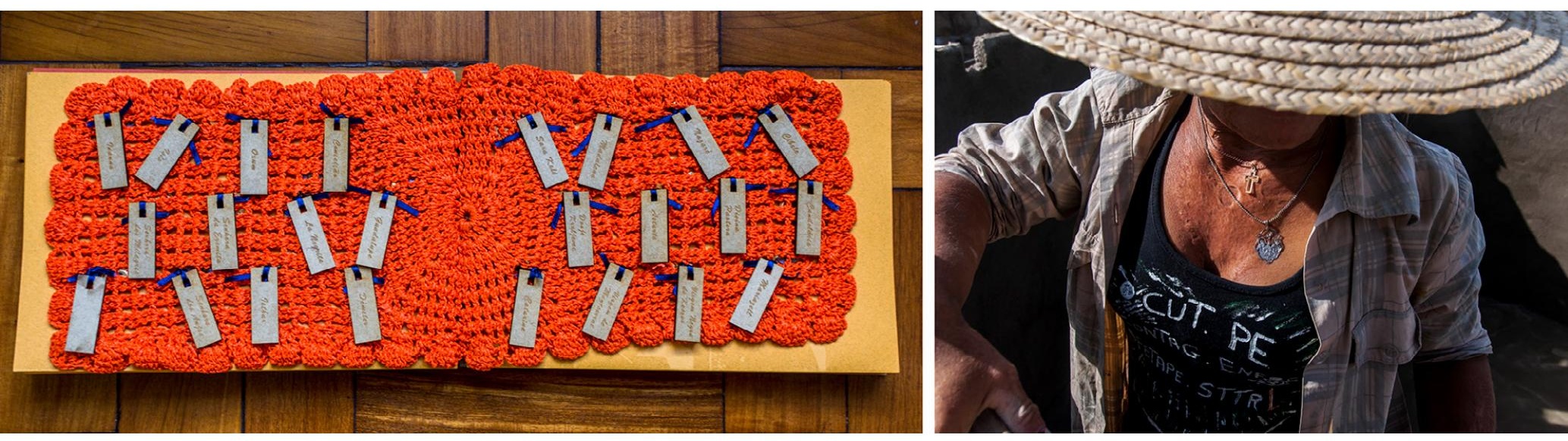

Figura 2

Ana Lira,

Terrane, 2018, livro de artista, $16 \times 5 \mathrm{~cm} \times 24 \mathrm{~cm}$,

Coleção da Artista. Foto: Ana Lira. Em destaque, fotografia de Ana Lira que faz parte do livro.
A aparência singela do livro guarda, na verdade, um documento afetivo e social sobre comunidades que resistem ao domínio de uma cultura de enfraquecimento da população nordestina que vive no chamado semiárido. Dessa forma, a tessitura entre as imagens e os documentos no livro parece configurar uma espécie de cartografia de afetos e, desse modo, Ana Lira investe-se na condição de uma fotocartógrafa para traçar uma delicada trama de sua experiência social no semiárido, no sentido como sugere Suely Rolnik: 
Sendo tarefa do cartógrafo dar língua para afetos que pedem passagem, dele se espera basicamente que esteja mergulhado nas intensidades de seu tempo e que, atento às linguagens que encontra, devore as que lhe parecem elementos possíveis para a composição das cartografias que se fazem necessárias. ${ }^{9}$

O livro mostra-se como um objeto cuidadosamente elaborado pela artista, cuja narrativa entrelaça todas as camadas e discursos que ora se intensificam como relato social, ora se expandem na experiência visual e fotográfica da artista. Muitas imagens que se firmam como a espinha dorsal da narrativa são construídas de modo eloquente e, ainda assim, não cedem à tentação ao espetáculo do discurso formal da arte. $O$ trabalho se deixa muito mais envolver-se pelas narrativas pessoais e os documentos familiares das mulheres e famílias que trabalham na construção das cisternas.

Alheia a qualquer estratégia de espetacularização visual, a delicada tessitura do livro remete, por sua sutileza e refinamento formal, aos biografemas de Roland Barthes. Este nos informa que, de uma breve experiência de vida, é possível destacar lembranças, fragmentos, passagens, inflexões, instantes fortuitos ou breves memórias dispersas, extraviadas. A esses pormenores considerados "insignificantes" de uma trajetória existencial, Barthes chamou de biografemas e que "pertencem ao campo do imaginário afetivo"10. Sob tal concepção, fragmentos de imagens e pequenos textos passam a ser enunciados como relevantes em uma narrativa visual, neste caso, de um processo artístico derivado de uma experiência social da autora.

Esse aspecto biografemático do trabalho se evidencia na experiência com a apreciação do livro no espaço da exposição revela-se uma experiência íntima, discreta, quase solitária, à maneira como habitualmente lemos um livro. Na montagem proposta pela artista, temos uma pequena mesa, dois bancos e o livro sobre a mesa, uma disposição de elementos que parece obedecer a mesma simplicidade do rigor formal do livro. Foi apenas acrescentada à montagem do espaço, uma imagem integrante do livro, aplicada numa parede ao lado da mesa; uma fotografia emblemática e contundente da força de trabalho das cisterneiras: a cisterna, em sua evidência concreta.

A potência visual da cisterna, como símbolo de grande impacto social e formal, nos leva a considerar o próprio objeto cisterna como objeto 
Figura 3

Ana Lira,

Terrane, 2018,

livro de artista,

$16 \times 5 \mathrm{~cm} \times 24 \mathrm{~cm}$,

Museu do Estado

do Pará - MEP,

Belém, 2018,

Coleção da

Artista, foto: Ana

Lira. Em destaque,

fotografia de cisterna de Ana

Lira que faz parte do livro. artístico, tal a contundência de seu peso físico que emerge da terra. A inequívoca propriedade estética de suas formas puras e singelas (cilindro e cone sobrepostos, de uma feitura quase minimalista) é realçada por uma majestosa e imaculada pintura branca em contraste com os tons terrosos do semiárido e com a arquitetura vernacular das casas do lugar e suas cores "tão verde-rosa que vão passando ao nos ver passar" ${ }^{11}$. Dessa forma, como "sábio projeto", a obra afirma-se conceitualmente por conta de seu valor simbólico, decorrente do significado que representa para a comunidade e por conta da experiência coletiva implícita no processo de sua artesania construtiva, executada pelas mãos de tantas mulheres daquele lugar, o que, finalmente, o converte em uma espécie de objeto-ação de uma práxis artístico-social.
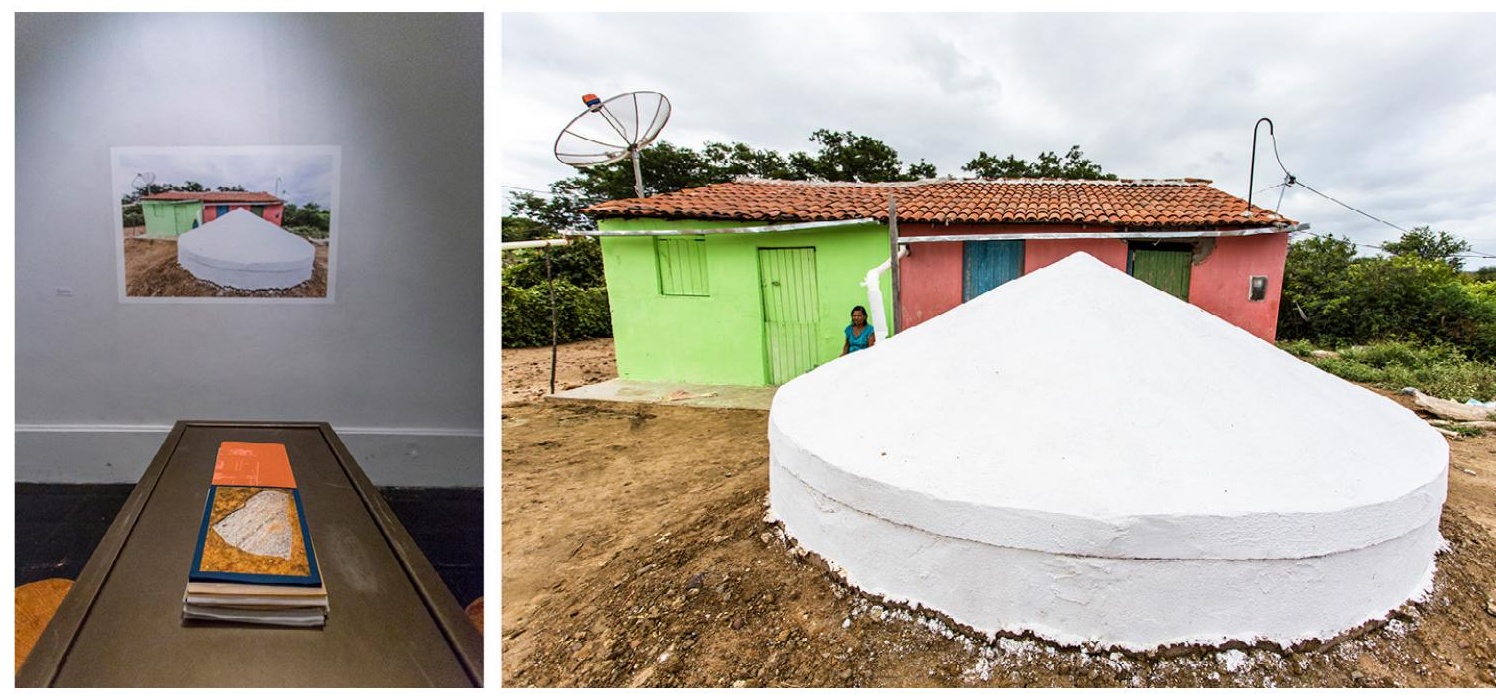

\section{Trauma de Ivan Padovani}

Aqui tudo parece construção e já é ruína Tudo é menino e menina no olho da rua $\mathrm{O}$ asfalto, a ponte, o viaduto ganindo pra lua Nada continua...

(Caetano Veloso, Fora da Ordem, 1991)

O trabalho de Ivan Padovani contrasta com a discrição da obra de Ana Lira. Juntos na mesma sala expositiva, observamos um confronto visível. Enquanto Terrane posicionava-se em um canto diminuto do espaço da sala, Trauma ocupa três paredes desse ambiente, metade da sala, constituído de várias peças de médio e grande formato, apresentando-se quase como 

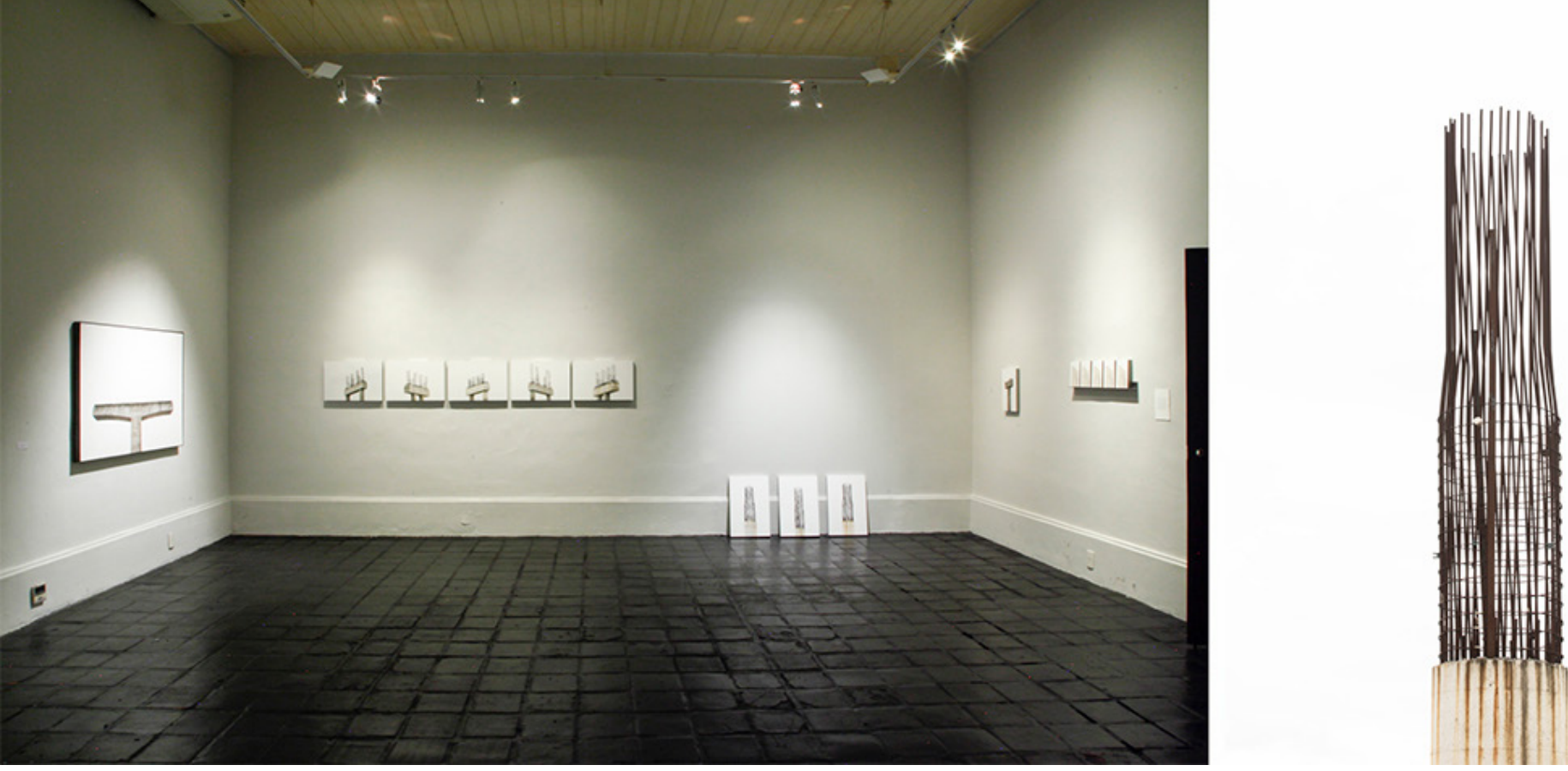

Figura 4

Ivan Padovani, Trauma, 2018, fotografia, dimensões variadas, Museu do Estado do Pará - MEP, Belém, 2018, Coleção do Artista, foto: Octavio Cardoso. Em destaque, fotografia de coluna de concreto de Ivan Padovani que faz parte do trabalho. uma instalação. Construído com absoluto rigor formal, o trabalho revela certa tradição estilística que remete à fotografia alemã, e, sob esse aspecto, mostra-se aparentemente fria, calculada. Nesse sentido, a objetividade das imagens de Padovani evoca o trabalho do casal de fotógrafos alemães Bernd e Hilla Becher, especialmente às séries de fotografias da arquitetura pós-industrial europeia, realizadas entre as décadas de 1950-70 e que, segundo a apreciação de Alice Koegel, assumem um caráter de esculturas:

Eles são escultores. Pelo menos na opinião do júri da Bienal de Veneza, que em 1990 concedeu o Leão de Ouro da Escultura a Hilla e Bernd Becher. No pavilhão alemão daquele ano, foram expostas as séries em preto-e-branco de instalações de fábricas, fornos enormes, silos e reservatórios de gás. Esculturas, contudo, os Becher nunca produziram. Eles simplesmente fotografam as paisagens industriais abandonadas. Sem eles, elas não teriam passado de "esculturas anônimas". O que os dois fotógrafos alemães fazem é fechar os olhos para a funcionalidade destas edificações, extraí-las do seu contexto original e ordená-las em série, transformando-as em "construções", "estruturas", "objetos". ${ }^{12}$

Em consonância com as considerações acima, as imagens de Padovani exibem-se escultóricas, de forma monumental, ressoando espetaculares em sua fisicalidade e preciosismo. Nas imagens observamos gigantescas estruturas de concreto armado, inacabadas, cujas fraturas deixam à mostra de forma dramática os esqueletos das armações de aço. 
As gigantescas estruturas, fotografadas de modo clínico, destituídas de qualquer efeito ilusório, resultam em imagens secas, como imensos monólitos paradoxalmente tão abstratos quanto concretos em sua figuração, o que nos conduz a uma experiência que a princípio parece se esgotar em um formalismo absoluto. No entanto, o conjunto de trabalhos, impressos em tamanhos variáveis, dispostos sobre a parede ou encostados ao chão e ainda acrescido de um pequeno texto, em uma percepção mais detida e acurada, começa a revelar-se como documentos de uma outra situação econômico-político-social: monumentos que encarnam as relações de poder e dinheiro, encarnam o enorme desperdício sobre a miséria social, a corrupção sistêmica e o discurso sinistro sobre a divisão de renda, indiciam projetos políticos ineficazes, alheios a qualquer compromisso com o desenvolvimento social. O que vemos, observando em uma duração mais larga de tempo ou em uma imersão mais física com os objetos, é a ostentação da ineficiência sob a forma de grandes projetos que resultam em obras inacabadas ${ }^{13}$, em um processo de construção e já ruína.

No plano da fisicalidade de ambos os trabalhos no espaço, experimentase a tensão: enquanto Padovani ergue um monumento de grande efeito plástico, com suas portentosas estruturas de concreto e aço, de construções arrastadas e inconclusas, Ana Lira retraça e desmonta qualquer motivação de monumentalizar seu objeto ao construir um diário compartilhado com comunidades de mulheres cisterneiras no sertão nordestino.

O que parece estritamente formal no trabalho do Ivan converte-se, na verdade, em um conjunto de símbolos nacionais de inacabamento e desperdício. Em contraponto e aproximação, observamos no trabalho de Ana, o relato em livro sobre a força e a perseverança em torno de outro objeto que passa a ter uma dimensão simbólica poderosa: a presença física e visual das cisternas, construídas pelas mulheres na região do semiárido nordestino, numa atitude francamente reativa à histórica simbologia dominante da indústria da seca, forjada pelo poder econômico. Nesse sentido, as cisternas podem ser compreendidas em sua forma,

13 Segundo auditoria realizada em 2018 pela área técnica do Tribunal de Contas da União, 38,4 mil obras encontram-se inacabadas ou paradas e representam investimento de R\$ 144 bilhões, mas somente cerca de R\$10 bilhões foram aplicados sem que tenha sido gerado qualquer benefício à população. (https://gl.globo.com/politica/ noticia/2019/05/15/tcu-diz-que-375percent-das-obras-financiadas-com-verba-dauniao-estao-paradas-ou-inacabadas.ghtml - acessado em 19/03/2020). 
paradoxalmente, como verdadeiros monumentos de forte simbolismo enquanto objeto de ação social.

No trabalho de Ivan, onde a forma minimalista parece dominar, há uma escrita sutil sobre o poder na solidez da eloquência objetual evocada pelas imagens das estruturas. No trabalho da Ana, onde a narrativa social se manifesta sob artesania mais barroca, intimista e pessoal incorporando cartas, tecidos e pequenos objetos, há uma espinha dorsal que estrutura o livro constituída por sofisticadas imagens que certamente poderiam ser apresentadas em grandes formatos na parede, mas que estão ali (no livro) para serem entrevistas e não necessariamente exibidas ostensivamente. A elegância escultórica de Trauma é um exercício formalista sim, exposta em sua eloquência, mas que se oferece igualmente como um contradiscurso a ser entrevisto: uma narrativa de poder que está impregnada nas vigasmonumento.

O modo operacional e poético com que Ana Lira lida com suas belas imagens é oriundo de uma postura própria sobre a matéria da arte com a qual decidiu trabalhar. Um tipo de construção que se dá no espaço social, de compartilhamento, um trabalho político em sua manifestação elementar no sentido de que é construído por meio de uma relação coletiva. Não que o livro seja um objeto coletivo, mas que para ele existir enquanto trabalho de uma artista, se faz intrinsecamente incorporando as vozes e as presenças daquelas pessoas que são o motivo da obra existir ${ }^{14}$. O trabalho existe na medida em que se faz como um construto social, que se dá na relação com o outro em duração de tempo que é a vida. Esse é o seu lugar. Nesse sentido, a lida de Ana com suas imagens é curiosamente um processo de recusa da beleza de suas imagens, um trabalho de abafamento da exuberância de várias de suas fotografias para que as imagens não falem mais alto do que as vozes das mulheres cisterneiras, não se sobreponham à narrativa labiríntica dos documentos e da convivência.

Em relação a Trauma de Ivan Padovani, temos blocos gigantes, sólidos, fotografados e seriados como um discurso explicitamente formal, e em seu modo elementar, engendrado no lugar da arte em seu sentido moderno mais tradicional, leitura possível no contato mais imediato 
com a obra. Isolados, distantes, silenciosos se mostram os objetos nas imagens do artista. Isolado, distante e silencioso, provavelmente se faz o processo operacional e poético do artista. No entanto, assim como podemos entrever, na espinha dorsal da narrativa social do livro, a beleza das imagens de Ana Lira, podemos sim, entrever a potência crítica em sentido político do conjunto de Ivan Padovani, pontuado especialmente por outros dois elementos textuais: o título do trabalho e o pequeno texto que acompanha o conjunto.

A palavra Trauma possui forte sentido no aspecto performativo do trabalho porque questiona a solidez das estruturas evidenciadas nas imagens. Reiterando esse termo, do ponto de vista da engenharia civil, trauma estrutural refere-se também aos problemas de fendas, trincas, fissuras e fraturas que ocorrem nas patologias do concreto armado, muitas vezes expondo o esqueleto metálico de tais estruturas. Portanto, uma terminologia técnica que realça o sentido traumático do "monumento", gigante mas frágil, algo que o texto inserido no trabalho, por sua vez, se encarrega de enfatizar, nos envolvendo por um sentimento de vulnerabilidade, fragilidade e leveza que contrasta com o que as imagens parecem afirmar.

Em contraponto, o termo Terrane adotado por Ana Lira, parece justamente indicar um ato de verificação mais atenta do terreno sobre o qual se pode atuar, construir, existir. Para a artista, o termo é incorporado como poética das relações mas está situado igualmente a partir da regra dos minerais, da geologia do lugar. Para as ciências geológicas, um terreno é um fragmento de crosta material formado por acreções, ou seja, acumulações de sedimentos, aumento de terra provocado por acomodações entre placas tectônicas convergentes cujo encontro provoca quebras que possibilitam a movimentação e o aumento de terrenos suturados a outras placas.

A superfície dos terrenos, com sua paisagem constituída por determinados tipos de vegetação são os índices para que o reconhecimento do tipo de terra determine o lugar mais propício sobre o qual irá ocorrer o trabalho de construção das cisternas, a direção mais acertada do caminho da água. Portanto, o trabalho de Ana Lira enuncia um certo rebatimento entre as relações geológicas e o fenômeno das relações sociais que se desenvolvem na busca por água na superfície, e na real concretização das soluções regidas por uma força coletiva e comunitária de aprendizado. A artista ressalta que embora sejam as mulheres as construtoras das cisternas, o trabalho não é feito sem a presença dos homens: 
Os homens, muitas vezes, são assistentes. Os filhos que estão ali e que vão aprender, também, para ajudar em casa, da mesma maneira que várias mulheres passam a construir cisterna para ajudar os pais, que também são pedreiros, porque é nesse processo de articulação que eles conseguem aumentar a renda da família e da comunidade. (...) Quando determinado tipo de vegetação está ali colocado é porque, naquela área, vai ser possível cavar cisterna. Se tiver um outro tipo de vegetação ou um outro tipo de pedra e de cor de areia, também, eles vão na aposta. Às vezes, encontram uma pedreira que ninguém sabia que existia. Às vezes, aquela pedreira abandonada vira uma outra coisa depois, pode virar a base para uma casa ou um tanque de pedra. ${ }^{15}$

É importante perceber que as nomeações de ambos, Trauma e Terrane potencializam os discursos formais em camadas de significação entre 0 científico e o estético, contribuindo para uma atenção aos índices que atuam sob e sobre as superfícies do objeto artístico, seja na narrativa afetuosa engendrada no livro de artista ou na aparência potente das vigas na fotografia formalista. Ambos projetos nos convocam a perceber suturas, entrever os paradoxos entre firmeza e debilidade nas questões ativadas por seus discursos.

\section{Considerações finais}

A análise proposta para Terrane de Ana Lira e Trauma de Ivan Padovani tem como motivação perscrutar as camadas discursivas de cada projeto em suas particularidades, mas também investigar o diálogo estabelecido por confrontações e aproximações apontadas por vários elementos. Dentre os elementos que nos permitem entrever, em cada um dos trabalhos tal potência discursivo-formal, identificamos finalmente dois componentes significativos do ponto vista indicial. Um deles é a fotografia de Ana Lira das ferramentas organizadas rigorosamente dentro do círculo de arame, em uma composição que remete à filiação alemã, em especial àquela vinculada à produção vanguardista chamada de Nova Objetividade. Notem que os equipamentos de trabalho estão em visão frontal e aérea "chapados" sobre a superfície - o chão, o solo, a terra - como numa espécie de estética de colagem. O formalismo de Ana aqui, assinala de modo sutil (em meio à quantidade de imagens e documentos que constituem o labirinto narrativo

15 Lira, 2018, Roda de Conversa. A ser publicada no catálogo IX Diário Contemporâneo de Fotografia. 

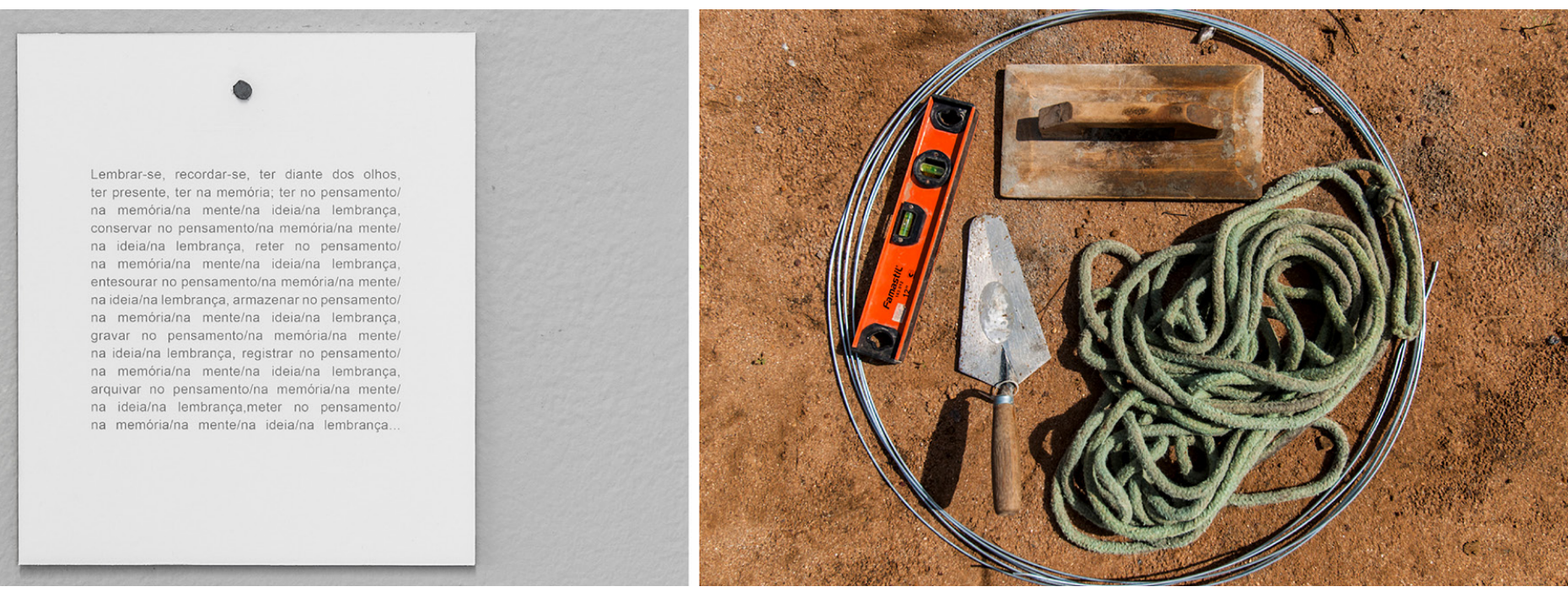

Figura 5 Fotografia de texto impresso de Ivan Padovani que faz parte de Trauma (Ivan Padovani, Trauma, fotografia/objeto, 2018, Coleção do Artista, foto: Octavio Cardoso. Fotografia de ferramentas de Ana Lira que faz parte do livro Terrane (Ana Lira, Terrane, livro de artista, 2018). do livro) a firmeza das histórias sociais coletivas vividas pela artista em conjunto com as mulheres cisterneiras.

O outro elemento a ser entrevisto é o texto francamente lírico, com traços de poema concreto e sonoridade simbolista utilizado por Ivan Padovani. Não se trata de poema ou texto produzido com fins literários. O artista extrai uma passagem da definição de memória, dentro da classe dos verbos no labiríntico Dicionário Analógico da Língua Portuguesa ${ }^{16}$, intervindo com o recorte (novamente observa-se a operação de montagem e/ou colagem) na nuvem de palavras originadas do verbo "lembrar". O que é definição em um dicionário, ainda que seja sob a natureza expandida das analogias típicas desse tipo de documento textual, ressurge com intenso sentido poético (e político) no deslocamento efetivado pelo artista. 0 sentido político que emerge desse deslocamento é um tanto discreto, mas fere, ao enfatizar as tentativas do ato de lembrar, a suposta fortaleza das colunas de concreto representadas de modo tão fixo nas imagens.

É notável perceber como ambos elementos - a fotografia de Ana Lira e o texto de Ivan Padovani - podem funcionar como um jogo de conversibilidade nas entrelinhas do trabalho de cada um. Curiosamente tais elementos poderiam estar um no espaço do outro: o formalismo de Ana Lira e o texto de Ivan Padovani. Notemos ainda que ambos poderiam se deslocar nesse jogo entre poética e política: o rigor plástico da fotografia de Ana 
como um signo próximo à estética de Trauma. O texto situado em Trauma como uma ferramenta de compreensão no livro Terrane. Neste sentido, concluímos que o jogo possível entre imagem e texto proposto nesta análise poderá ampliar a experiência dos trabalhos no encontro espaçotemporal com o público.

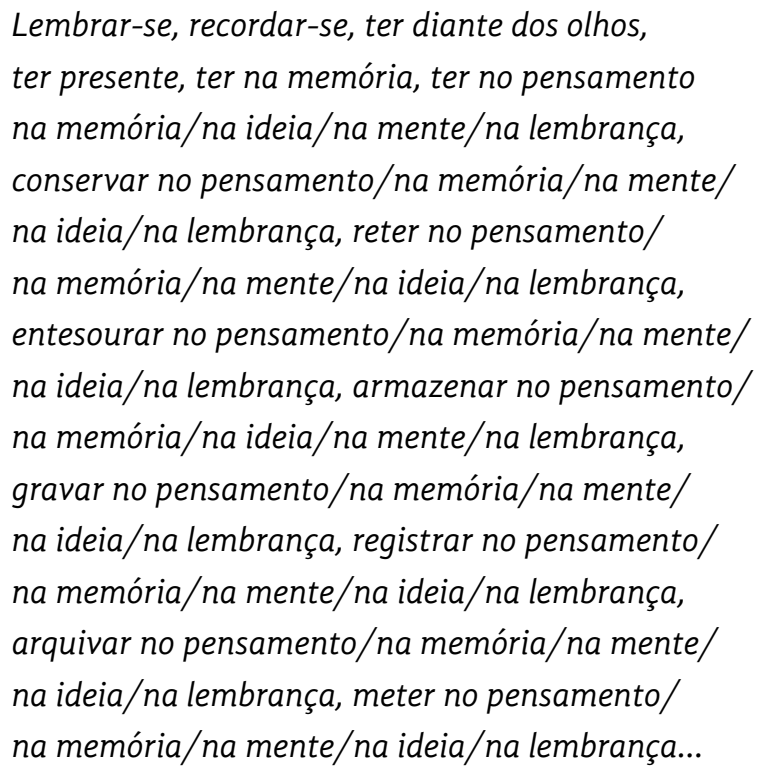

\section{REFERÊNCIAS}

ARGAN, Giulio Carlo. Arte e crítica de arte. Lisboa: Editorial Estampa, 1988.

AZEVEDO, Francisco Ferreira dos Santos. Dicionário Analógico da Língua Portuguesa, Editora Lexikon, 2010.

BARTHES, Roland. O Rumor da Língua. Trad. Mario Laranjeira. São Paulo: Martins Fontes, 2004.

BELTING, Hans. O fim da história da arte: uma revisão dez anos depois. São Paulo: Cosac Naify, 2006.

DANTO, Arthur. Após o fim da arte: a arte contemporânea e os limites da história. Trad. de Saulo Krieger, Posfácio à edição brasileira de Virgínia H. A. Aita. São Paulo: Odysseus Editora, 2006.

KOEGEL, Alice. As "esculturas anônimas" de Hilla e Bernd Becher. 2006. disponível em: https://www.dw.com/pt-br/as-esculturasan\%C3\%B4nimas-de-hilla-e-bernd-becher/a-2186162-0

LIRA, Ana. Dossiê do projeto Terrane, apresentado ao edital do IX Prêmio 
Diário Contemporâneo, 2018.

LIRA, Ana. KLAUTAU FILHO, Mariano - Roda de conversa Narrativas em presentificação: um diálogo com o projeto Terrane. Mediação por Mariano Klautau Filho, julho de 2018 no Museu do Estado do Pará - IX Prêmio Diário de fotografia. Material transcrito a ser publicado no catálogo do projeto.

MAMMI, Lorenzo. O que resta : arte e crítica de arte / Lorenzo Mammì. $1^{\text {a }}$ ed. - São Paulo : Companhia das Letras, 2012.

OSBORNE, Peter. "Arte conceptual y/como filosofia in El arte más allá de la estética. Ensayos filosóficos sobre arte contemporâneo”. CENDEAC, 2010.

ROLNIK, Suely. Cartografia Sentimental: transformações contemporâneas do desejo. Porto Alegre: Sulina; Editora UFGRS, 2006.

SEKULA, Allan. Desmantelar la modernidad, reiventar el documental: notas sobre la política de la representación. In: RIBALTA, Jorge. Efecto real: debates posmodernos sobre fotografía. Barcelona: Editorial Gustavo Gigli, SA, 2004. 